\title{
Development of Equalization Tank for flow rate attenuation in small scale Wastewater Treatment System
}

\author{
N.A. Raji ${ }^{*}$, J.O. Olaleye ${ }^{1}$, R.O. Ogunleye ${ }^{2}$, A.T. Anibaba ${ }^{1}$ \\ ${ }^{1}$ Mechanical Engineering Department, Lagos State University, Nigeria \\ ${ }^{2}$ Krestfield Engineering Ltd, Lagos. Nigeria \\ *e-mail: Nurudeen.raji@lasu.edu.ng \\ Received: $20^{\text {th }}$ August 2016 \\ Accepted: 21st October 2017 \\ Published:16 ${ }^{\text {th }}$ March 2018 \\ https://doi.org/10.47545/etrj.2018.3.1.034
}

\begin{abstract}
ABSTARCT
A prototype equalization tank was developed for the treatment of 250 litres of domestic waste water per hour. The tank was fabricated from mild steel plate with pipe network, the lift pump and air blower. Five samples run of wastewater flow was tested with the tank for 150, 175, 200, and 225 litres of wastewater. The equipment was found to be effective at wastewater inpt flow volume of 175 liters per hour. However the highest recovery was obtained at the input rate of 200 liters per hour of the wastewater, he equipment was not performing optimally at this recovery quantity. The study inferred that equalization becomes essential to obtain proper performance of the treatment plant.
\end{abstract}

Keywords: Aeration, Effluent, Equalization, Influent, Plant, Tank, Treatment, Wastewater,

\section{INTRODUCTION}

Wastewater is any water that has been affected by human use [1]. The wastewater is used water from any combination of domestic, industrial, commercial, or agricultural activities, surface runoff or storm water, and any sewer inflow or sewer infiltration. It is a by-product of domestic, industrial, commercial or agricultural activities.

The characteristics of wastewater vary depending on the source, types of wastewater include; domestic wastewater from household, municipal wastewater from communities (also called sewage) or industrial wastewater from industrial activities.

Wastewater can contain physical, chemical and biological pollutants [2]. Pollutants are specific contaminants leading to water pollution and this includes a wide spectrum of chemicals, pathogens, and physical changes such as elevated temperature and discoloration. While many of the chemicals and substances that are regulated maybe naturally occurring (calcium, sodium, iron, manganese, etc.) the concentration is one of the key in determining what a natural component of water is and what a contaminant is. These pollutants include: detergents, disinfection by-products; found in chemically disinfected drinking water such as chloroform, food processing waste; oxygen demanding substances, fats and grease, insecticides and herbicides, petroleum hydrocarbons including fuels and lubricants (motor oil) fuel and combustion by-products from storm water runoff, volatile organic compounds; such as industrial solvents from improper storage, chlorinated solvents, perchlorate, drug pollution involving pharmaceutical drugs and their metabolites.

The wastewater treatment plant is usually designed for purpose of improving the quality of wastewater. Small scale wastewater treatment system had earlier been developed and tested [3]. Ansari and Pandey [4] developed a conceptual design for wastewater treatment plant purposely to prevent the contamination of aquifer, and also to minimize the environmental impacts on the environment. A small scale wastewater treatment plant has also been modeled [5]. The plant is usually designed such that suspended organic and inorganic solids including other wanted materials are removed [6].

Municipal wastewater is treated in sewage treatment plants, Agricultural wastewater may be treated in agricultural wastewater treatment processes, whereas industrial wastewater is treated in industrial wastewater treatment processes. Ahmed et al [7] studied wastewater treatment in textile industry. The study recommended a treatment option for textile industry which generates liquid waste. 
Water quality is a term that describes the physical, chemical and microbiological characteristics of water. These properties collectively determine the overall water quality and the fitness of the water for a specific use. Water

that is fit for domestic use must comply with some specific requirements as stated in [8]. The most important requirement is that it must be safe to drink, it must also be aesthetically pleasing and it must furthermore be chemically stable that is it must not cause corrosion or form deposits in pipes or fixture such as geysers.

Techniques for wastewater treatment include physical process, chemical process and biological processes. The physical process includes the preliminary treatment and primary clarifier, the biological process includes the aeration tank and the secondary clarifier, while the final stage which is the chemical process includes the disinfection, then we get the final effluent.

Physical methods of wastewater treatment accomplish removal of substances by use of naturally occurring forces, such as gravity, and electrical attraction [9]. In general, the mechanisms involved in physical treatment do not result in changes in chemical structure of the target substances. In some cases, physical state is changed, as in vaporization, and often dispersed substances are caused to agglomerate, as happens during filtration. Physical methods of wastewater treatment include sedimentation, flotation, and adsorption, as well as barriers such as bar racks, screens, deep bed filters, and membranes.

Physical methods of wastewater treatment can also be referred to as the representation of a body of technologies that we refer largely to as solid-liquid separations techniques, of which filtration plays a dominant role. Filtration technology can be broken into two general categories conventional and non-conventional. This technology is an integral component of drinking water and wastewater treatment applications. It is, however, but a one-unit process within a modern water treatment plant scheme, whereby there are a multitude of equipment and technology options to select from depending upon the ultimate goals of treatment. To understand the role of filtration, it is important to make distinctions not only with the other technologies employed in the cleaning and purification of industrial and municipal waters, but also with the objectives of different unit processes.

\section{MATERIALS AND METHODS}

The equalization tank was developed to retaining high flow fluctuations by providing steady influent flow for the use of the downstream processes of waste water treatment. The tank was fabricated as an assembly of a tank, air-blower, lift-pump, and PVC and stainless steel pipes as shown in Figure 1.

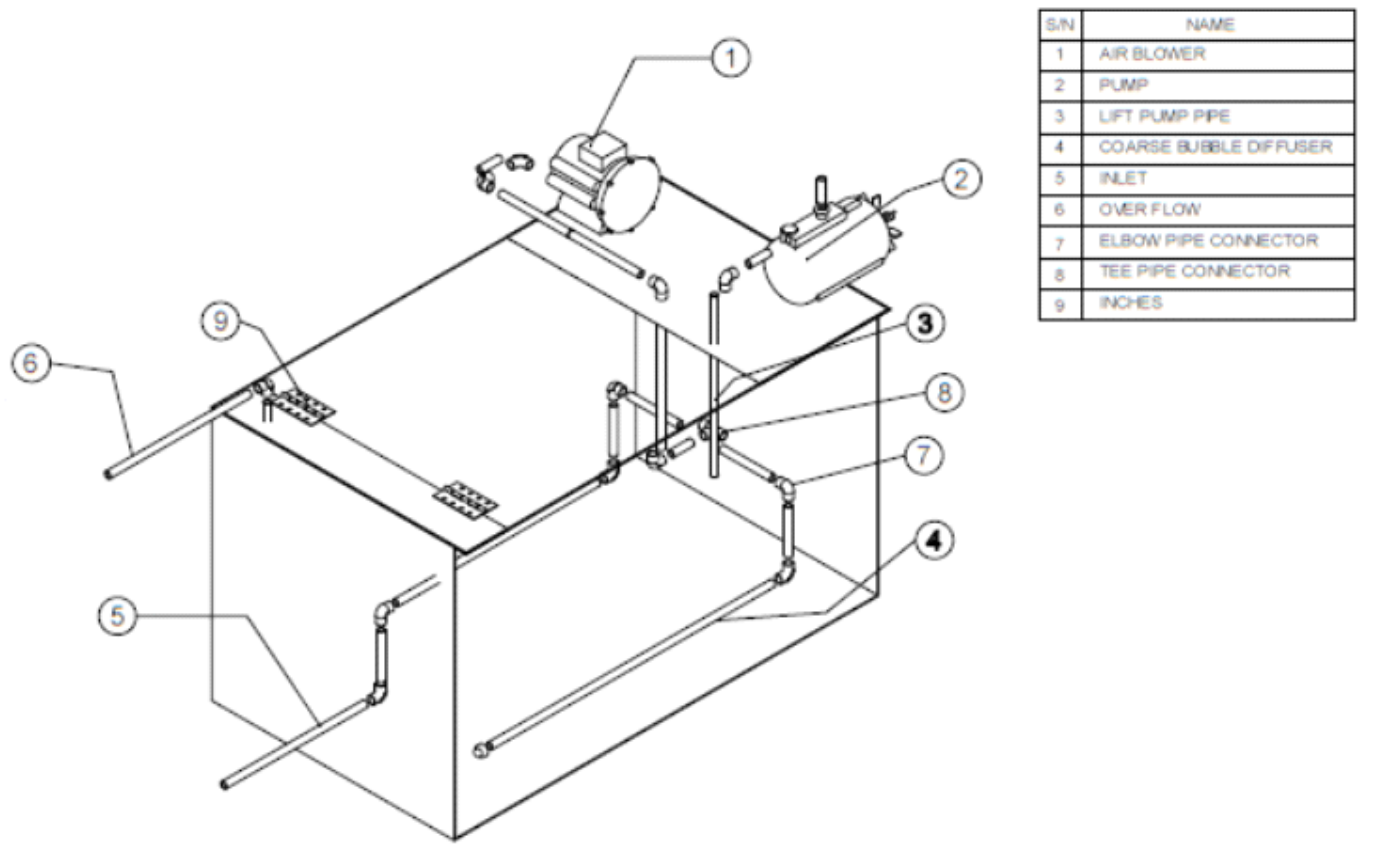

Figure 1: The equalization tank 
The oxygen $\left(\mathrm{O}_{2}\right)$ in the aeration tank is supplied by surface diffused aeration equipment. Wastewater passes into the tank for storage and then an air blower was used to pass oxygen into the tank filled with wastewater through a means of laid out pipe perforated at the extreme bottom end below the tank surface so that biological reaction can take place. The arrangement ensured that bacteria are kept alive to eat up any available solid and thereby convert it to a more liquid solvent making it easier to treat.

Effluent from the collection tank flows to the equalization tank in wastewater treatment. The main function is to act as buffer. To collect the incoming raw effluent that comes at widely fluctuating rates and position to the rest of the effluent treatment plant at steady flow rate. The equalization tank stores the effluent and lets it out during the non-peak time when there is no more incoming effluent. The inlet pipe of equalization tank carries filtered effluent from cooling tower. The coarse bubble diffusers made of short length tubes were perforated at regular spacing so as to release large bubbles in the tank to lightly aerate the effluent and also to agitate the mix continuously. Compressed air from blowers through was passed through the air supply pipe line into the tank.

The tank was built with mild steel of $3 \mathrm{~mm}$ thickness in size as defined in equation (1), The tank was then coated with anti-corrosive spray paint to prevent corrosion. The air-blower was installed to provide oxygen mix in the tank. The lift-pump was used to lift out the stored, aerated wastewater out of the tank into the other unit processes which is the flocculation tank.

$v=l x w x d$

Where $v$ is the volume of the tank, $l$ is the length of the tank, $w$ is its width, and $d$ is the depth.

The air blower and the lift pump are both of capacity $1 \mathrm{hp}$ each, the first pipe connected to the air blower was laid out on the tank and was later split in two inside the tank to form the coarse bubble diffuser which will allow efficient aeration of the wastewater and it is also held firmly a gripping handle made from mild steel welded to the bottom of the tank to avoid loosening of the pipes when the machine is in operation. The other pipe from the lift pump were laid down into the centre of the tank for lifting the partially cleaner water from below the tank after consequent aeration processes.

\section{RESULTS AND DISCUSSION}

The equalization tank constructed has a capacity to contain 250 litres of wastewater. Effluent wastewater was infused (pumped in manually) into the tank for storage and was later aerated $\left(\mathrm{O}_{2}\right.$ was blown into the water to keep the bacteria in the wastewater alive to then eat up any remaining solid in the wastewater by turning them into a more liquid solvent to make it easy for processing in the other units).

The aeration is done constantly and sludge's that float at the surface of the water are removed manually, this process is continued for hours or a day depending on how cleaner we want the water to be before it is pumped out and released into another unit process taking into consideration that the normal detention time for a standard full plant is 2 hours, so for this design the detention time would be $\leq 5$ hours. After which the water still containing dirt is pumped out from the bottom of the tank immediately when an aeration operation just stopped which allows the bottom to a point at the top of the tank filled with water to be partially cleaner than the top (uppermost) layer of the tank which is filled with dirt floating on the surface.

This process was carried out for different quantity of water input into equalization tank and the detention Time/Total Processing Hours (Total time for storage, aeration of wastewater and extraction of the output) was recorded. The recovery for the further chemical treatment was determined in Extracted litres/Total Processing hour.

The technical evaluation of the developed equalization tank was carried out using set of input waste water volumes of 150, 175, 200, 225 litres respectively as shown in Table 1.

The tank of 250 litres was not filled to the brim to compensate for overflow and bubbles. These values were arbitrary chosen to evaluate its recovery at different water tank level as a result of different height and pressure at different levels of the fluid to the coarse bubble diffusers.

From Table 1 the recovery quantity extracted per total processing hours increases with the input of wastewater into the equalization tank up to a certain level of about $43 \mathrm{l} / \mathrm{hr}$ for 200 litres water input after which the recovery reduces with increasing wastewater input. Further increase in the volume of wastewater prevents sufficient 
aeration and proper dissolution of the solvent present in the liquid at the top due to increasing altitude from the coarse diffuser.

Table 1: Quantity of extracted waste after aeration/total processing hours.

\begin{tabular}{lllll}
\hline $\begin{array}{l}\text { Waste water } \\
\text { input (ltr) }\end{array}$ & Output (ltr) & $\begin{array}{l}\text { Output/input } \\
\text { ratio }\end{array}$ & $\begin{array}{l}\text { Processing hour/ } \\
\text { detention time }\end{array}$ & $\begin{array}{l}\text { Recovery } \\
\text { (ltr/hr) }\end{array}$ \\
\hline 225 & 193 & 0.86 & 4.75 & 40.6 \\
200 & 172 & 0.86 & 4.00 & 43.0 \\
175 & 161 & 0.92 & 4.25 & 37.9 \\
150 & 128 & 0.85 & 3.50 & 36.6 \\
\hline
\end{tabular}

It was observed that although the highest yield was obtained at 200litres wastewater input but the tank favors a higher yield at 175 litres wastewater input. The yield at this level was $92 \%$ as against $86 \%$ for the highest recovery.

It therefore could be said that although the equalization tank is designed to accommodate 250 litres of wastewater for processing, it should be recommended that the input wastewater into this constructed tank should be $\leq 175$ litres for cost and performance efficiency.

\section{CONCLUSION}

The equalization tank for domestic waste water treatment was developed. The tank was designed to accommodate 250 litres of waste water per hour. A performance evaluation was then performed to attain the efficiency of the tank, output time, detention time and recovery time of the tank respectively. The function of a wastewater treatment plant is to improve the quality of wastewater by removing suspended organic and inorganic solids and other materials before discharging it into a waterway. However, for sewage treatment plant of small community, where wastewater flow rate considerably vary with time, equalization becomes essential to obtain proper performance of the treatment plant.

\section{REFERENCES}

[1]. T.E. Ulrich, L. Lüthi, C. Reymond, Ph. Zurbrügg Compendium of Sanitation Systems and Technologies (2nd Revised Edition). Swiss Federal Institute of Aquatic Science and Technology (Eawag), Duebendorf, Switzerland. p. 175.

[2]. E. Friedler, and E. Pisanty (2006). Effects of design flow and treatment level on construction and operation costs of municipal wastewater treatment plants and their implications on policy makin. Water Research, vol. 40(20). pp. 3751-3758.

[3]. Fu E. Tang, and V.J. Ngu (2011). A Study of Performance of Wastewater Treatment Systems for Small Sites. International Scholarly and Scientific Research \& Innovation 5(12), pp. 804-810

[4]. F. Ansari \& Yashwant K. Pandey (2013). Conceptual Design of a Wastewater Treatment Plant for the Dera Bassi Industrial Estate, Punjab (India). Global Journal of Science Frontier Research Environment \& Earth Science Vol. 13(4) pp. 1-10

[5]. O.A. Ezenwa, A. Chukwudi, N. Chinedu (2014). Modelling of a Small Scale Waste Water Treatment Plant (SSWWTP). West African Journal of Industrial \& Academic Research Vol.11(1), pp. 3-17

[6]. T.M. Manderso (2018). Determination of the Volume of Flow Equalization Basin in Wastewater Treatment System. Civil and Environmental Research Vol.10, No.4, pp. 34-41 
[7]. F. Ahmed, D. Bangladesh, Md. A. Hossain, T. Tamanna. Design evaluation of an effluent treatment plant. 4th Annual Paper Meet and 1st Civil Engineering Congress, December 22-24, 2011, Dhaka, Bangladesh.

[8] I.S. Oji, N.P. Chukwuma, and N.K. Friday, P.E.O. Philip (2018). Domestic Wastewater Treatment and Reuse in Awka Urban, Anambra State, Nigeria. International Journal of Geography and Environmental Management, vol. 4(2), pp. 16-24

[9]. Nicholas P Cheremisinoff. Handbook of Water and Wastewater Treatment Technologies. 1st Ed. 2001. Pp.576 